\title{
A Pedagogical Canon for Electric Guitar: An Australian Cultural Perspective
}

\author{
Daniel A. Lee \\ Charles Darwin University, Australia \\ e-mail: daniel.lee@utas.edu.au
}

Published online: 1 September 2018

Cite this article (APA): Lee, D. (2018). A pedagogical canon for electric guitar: An Australian cultural perspective. Malaysian Journal of Music, 7, 58-77.

\begin{abstract}
This study aimed to develop an up-to-date canon for electric guitar for use in popular music education in Australia through research of relevant industry data. A prospective pedagogical canon of ten songs was derived and discussed with suggestions for further curricula content and exemplars proposed. Quantitative and qualitative methodologies were employed to analyse data collected from a variety of industry sources. Findings of the study revealed some enlightening cultural insights from the perspective of Australian music education. The development of electric guitar culture in Australia was shown to be driven by international influences with Australia following the lead from the United States and the United Kingdom rather than offering uniquely Australian input. These factors may have led to a potential stifling of a uniquely Australian electric guitar culture via the widespread use of pedagogical methodologies that have simply adopted international content rather than focussed on development of local input.
\end{abstract}

Keywords: Australian culture, canon, contemporary popular music, electric guitar, pedagogy. 


\section{Introduction}

This paper reports on a study, conducted in Australia, which investigated the development of an instrumental teacher's personal canon of exemplars for use in delivering tuition on the electric guitar within a popular music education framework. The purpose of the development of the canon was for the personal reference of an instrumental instructor as a basis to derive a series of lesson plans which consistently address important pedagogical factors in teaching electric guitar. The setting that formulated the framework for this study is a private instructor teaching Australian secondary students in one-on-one instrumental tuition. The term 'canon' is often used to describe a list of compositions which a student of a particular instrument would be expected to include in their standard repertoire. However, in this study, in the absence of an alternative terminology, the term 'canon' is used to describe a list of songs for pedagogical reference, not performance expectations. It is anticipated that other instrumental tutors could replicate this approach to derive their own personal pedagogical canon informed by their particular socio-cultural locale. The canon developed in this study was aimed to be both musically and pedagogically relevant for students of electric guitar to develop them for the current global music marketplace.

The majority of Western art instruments already have their own canons and, in many cases, dedicated pieces have been written expressly for a specific purpose of developing the students' technical or musical development. These compositions are found in the curricula of music education institutions and organisations globally. The role the electric guitar has played in twenty-first century music is complex and dynamic crossing many genre borders and pioneering new ones. As a result, a natural evolution of a canon for electric guitar has not occurred.

The research project addressed the following question: Which compositions constitute a relevant repertoire for an electric guitar tuition curriculum? In order to position the findings within a global perspective of cultural and pedagogical significance, the following secondary research question was also investigated: What is the place and identity of Australian culture, through the lens of the electric guitar canon, in a globalised context?

Since the introduction of the Internet, the global music marketplace has undergone significant changes. In conjunction with other technological developments there has been a trend towards online marketing and self-produced music. The musician employment marketplace has experienced a shift toward a globalised perspective. The next generation of musicians will be competing on an international stage, via the Internet and their education should be preparing them for this.

With a focus on commercial compositions rather than purely educational or technical works, a student's repertoire is potentially more practically focussed as they enter the global marketplace as an early-career professional musician. Careful selection of an educational canon may still allow an instructive focus on technique, as well as musical theory and general knowledge by using appropriate significant historical and relevant compositions. Jodi Fisher makes a case for the use of songs 
in place of exercises; "students will learn the most from songs, they are the perfect vehicle for learning both theory and technique" (Fisher, 2005, p. 72). From a broader view on pedagogy, Pratchett states, "The best kind of education possible is the one that happens while you think you're having fun" (Pratchett, 2014, p. 120). It is the belief and experience of the author that students will enjoy learning songs more than technical exercises and a carefully derived pedagogical canon of songs can be designed to contain the technical and theoretical content found in method books and curricula.

\section{Methodology}

The study used a mixed methodology of quantitative and qualitative processes. This is now common practice in the social sciences (Sarantakos, 2013) and is becoming more typical in music research (Wise, 2014). The decision to use a mixed methods approach was made due to the type of data collected. The research was conducted through analysing information from syllabuses, curricula, publications and industry discourse ranging from the 1950's to the current era. The data collection also reflected the influence of the Internet on instrumental electric guitar tuition by the inclusion of data from Internet-only sources and publications with a strong Internet presence.

Syllabuses from music examination boards and guilds in Australia, the United States of America, Canada and the United Kingdom provided initial sources of quantitative data enabling the establishment of a list of songs occurring most frequently across the globe in modern guitar curricula. A second relevant source of data was industry discourse, internet sites and other current industry media offering tutorage in electric guitar. Table 1 shows the data sources for the syllabus and industry discourse data sets and their nationalities.

The third source of data was the personal records of the researcher, an Australian music educator, collected across ten years. The music educator's lesson plans comprise repertoire selected for pedagogical reasons and is heavily influenced by student feedback, via personal discourse on the choice of material and also by students' requests. Quantitative analysis was used to initially tabulate data from the primary sources to identify potential canon content by frequency of occurrence in pedagogical settings. Table 2 shows twenty most frequently listed songs from each of the three data sets and the frequency of occurrence. This list formed the basis for the qualitative analysis. 
Table 1

Data sources and nationalities

\begin{tabular}{|c|c|c|c|}
\hline Syllabus data source & Nationality & $\begin{array}{l}\text { Industry discourse } \\
\text { data source }\end{array}$ & Nationality \\
\hline $\begin{array}{l}\text { Australian Music } \\
\text { Examinations Board } \\
\text { Contemporary Popular } \\
\text { Music course }\end{array}$ & Australia & $\begin{array}{l}\text { Guitar World: } 50 \\
\text { Greatest Rock Songs }\end{array}$ & $\begin{array}{l}\text { United States of } \\
\text { America }\end{array}$ \\
\hline $\begin{array}{l}\text { Boosey \& Hawkes } \\
\text { Registry of Guitar Tutors } \\
\text { Rock Guitar Syllabus }\end{array}$ & $\begin{array}{l}\text { United } \\
\text { Kingdom }\end{array}$ & $\begin{array}{l}\text { VH1: Greatest Songs of } \\
\text { Rock and Roll }\end{array}$ & $\begin{array}{l}\text { United States of } \\
\text { America }\end{array}$ \\
\hline Canada Conservatory & Canada & $\begin{array}{l}\text { New Musical Express: } \\
50 \text { Greatest Guitar } \\
\text { Solos }\end{array}$ & United Kingdom \\
\hline $\begin{array}{l}\text { Victorian Curriculum and } \\
\text { Assessment Authority }\end{array}$ & Australia & $\begin{array}{l}\text { Guitar World: } 100 \\
\text { Greatest Guitar Solos }\end{array}$ & $\begin{array}{l}\text { United States of } \\
\text { America }\end{array}$ \\
\hline Heanor School of Music & $\begin{array}{l}\text { United } \\
\text { Kingdom }\end{array}$ & $\begin{array}{l}\text { Rolling Stones } \\
\text { Magazine: Greatest } \\
\text { Guitar Songs of All } \\
\text { Time }\end{array}$ & $\begin{array}{l}\text { United States of } \\
\text { America }\end{array}$ \\
\hline $\begin{array}{l}\text { Australian Guild of Music } \\
\text { and Education }\end{array}$ & Australia & $\begin{array}{l}\text { Guitar Alliance: Top } \\
\text { Classic Rock Songs }\end{array}$ & $\begin{array}{l}\text { United States of } \\
\text { America }\end{array}$ \\
\hline $\begin{array}{l}\text { Trinity College London, } \\
\text { Pop and Rock }\end{array}$ & $\begin{array}{l}\text { United } \\
\text { Kingdom }\end{array}$ & $\begin{array}{l}\text { Guitar Habits: } 20 \text { Guitar } \\
\text { Classics }\end{array}$ & Netherlands \\
\hline Hot Rock Guitar & $\begin{array}{l}\text { United States of } \\
\text { America }\end{array}$ & $\begin{array}{l}\text { Guitar Tricks: Jam } \\
\text { Sessions Songs }\end{array}$ & $\begin{array}{l}\text { United States of } \\
\text { America }\end{array}$ \\
\hline Berklee College of Music & $\begin{array}{l}\text { United States of } \\
\text { America }\end{array}$ & $\begin{array}{l}10 \text { Greatest Guitar } \\
\text { Songs of All Time - For } \\
\text { Dummies }\end{array}$ & $\begin{array}{l}\text { United States of } \\
\text { America }\end{array}$ \\
\hline
\end{tabular}

The qualitative component of the study was conducted using critical analysis as the methodology. The researcher felt this methodology most closely supports the intended research process (Denzin \& Lincoln, 2011). Each of the songs in the table above were examined for pedagogical value by cross referencing their content to studies, etudes and compositions found in guitar tutor and method books. The tunes found to contain the most comparatively similar content were considered to be of higher pedagogical value and therefore greater status for the purpose of the 
canon being derived in this study. For example the Australian publication Progressive Lead Guitar (Turner \& White, 1979a) is a very popular guitar tutor book in Australia. The first lesson introduces the twelve-bar-blues harmonic progression and through a series of exercises builds a riff based blues exercise. The Ray Charles composition 'What'd I Say' is an example of a simple riff-based blues composition. Figure 1 shows the Turner and White exercise and Figure 2 shows Charles' 'What'd I Say' for comparison.

Table 2

Top twenty songs in each data set

\begin{tabular}{|l|c|l|c|l|c|}
\hline Syllabuses & $\#$ & Industry Discourse & $\#$ & Tutor Log & $\#$ \\
\hline Sunshine of Your Love & 7 & Stairway to Heaven & 9 & What'd I Say & 342 \\
\hline Whiteroom & 4 & Freebird & 6 & Hey Joe & 233 \\
\hline Under the Bridge & 4 & Hotel California & 6 & $\begin{array}{l}\text { Sweet Home } \\
\text { Alabama }\end{array}$ & 149 \\
\hline The Wind Cries Mary & 4 & $\begin{array}{l}\text { Smells Like Teen } \\
\text { Spirit }\end{array}$ & 6 & Boom Boom & 132 \\
\hline Sweet Child of Mine & 4 & Sweet Child of Mine & 6 & Flintstones Theme & 87 \\
\hline Sultans of Swing & 4 & $\begin{array}{l}\text { All Along the } \\
\text { Watchtower }\end{array}$ & 6 & $\begin{array}{l}\text { All Along the } \\
\text { Watchtower }\end{array}$ & 77 \\
\hline Paranoid & 4 & Beat It & 5 & La Bamba & 60 \\
\hline Crossroads & 4 & Crossroads & 5 & $\begin{array}{l}\text { Sunshine of Your } \\
\text { Love }\end{array}$ & 52 \\
\hline $\begin{array}{l}\text { You Shook Me All } \\
\text { Night Long }\end{array}$ & 3 & Purple Haze & 5 & Purple Haze & 51 \\
\hline Wonderful Tonight & 3 & Whole Lotta Love & 5 & Vertigo & 51 \\
\hline Tears In Heaven & 3 & Bohemian Rhapsody & 4 & Summer of ‘69 & 48 \\
\hline Stairway to Heaven & 3 & Crazy Train & 4 & $\begin{array}{l}\text { Hero } \\
\text { (Nickleback) }\end{array}$ & 47 \\
\hline Panama & 3 & Eruption & 4 & Can’t Stop & 45 \\
\hline One (Metallica) & 3 & Johnny B. Goode & 4 & Zebra & 43 \\
\hline Misty & 3 & Layla & 4 & La Grange & 40 \\
\hline Living on a Prayer & 3 & Walk This Way & 4 & Kryptonite & 39 \\
\hline Little Wing & 3 & You Really Got Me & 4 & Bad to the Bone & 37 \\
\hline Layla & 3 & Back in Black & 3 & Johnny B. Goode & 36 \\
\hline How High the Moon & 3 & Comfortably Numb & 3 & $\begin{array}{l}\text { Are You Gonna } \\
\text { Be My Girl }\end{array}$ & 35 \\
\hline Hey Joe & 3 & Killing in the Name & 3 & Hotel California & 35 \\
\hline
\end{tabular}

\# - frequency of occurrence within each data set. 
Here is the complete 12 bar in A:

RIFF ONE
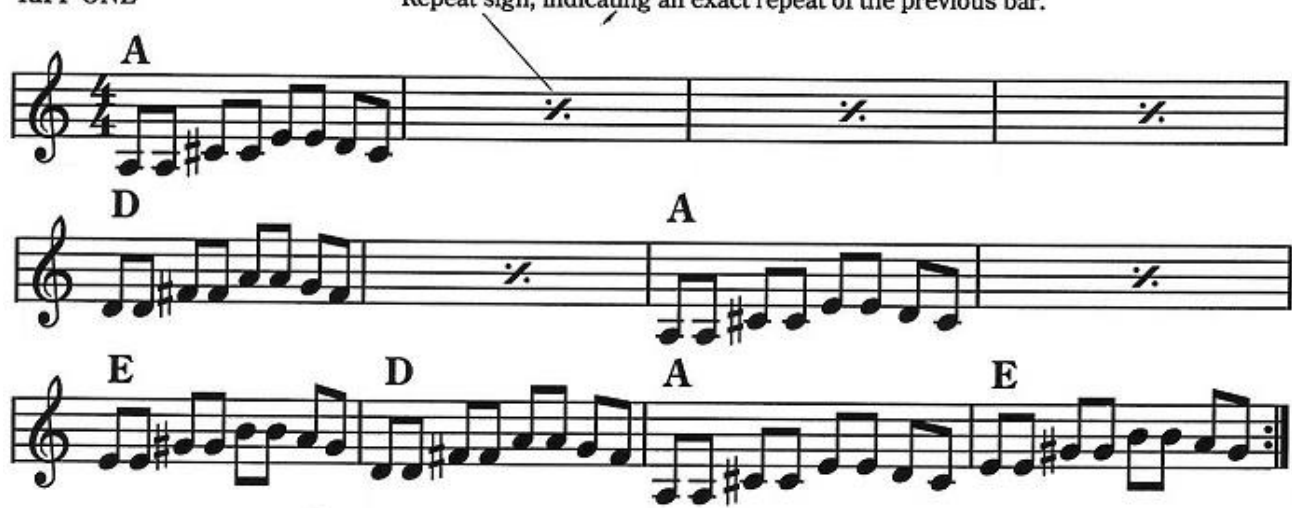

Figure 1 Progressive Lead Guitar- 'Exercise 4' (Turner \& White 1979a, p. 12)
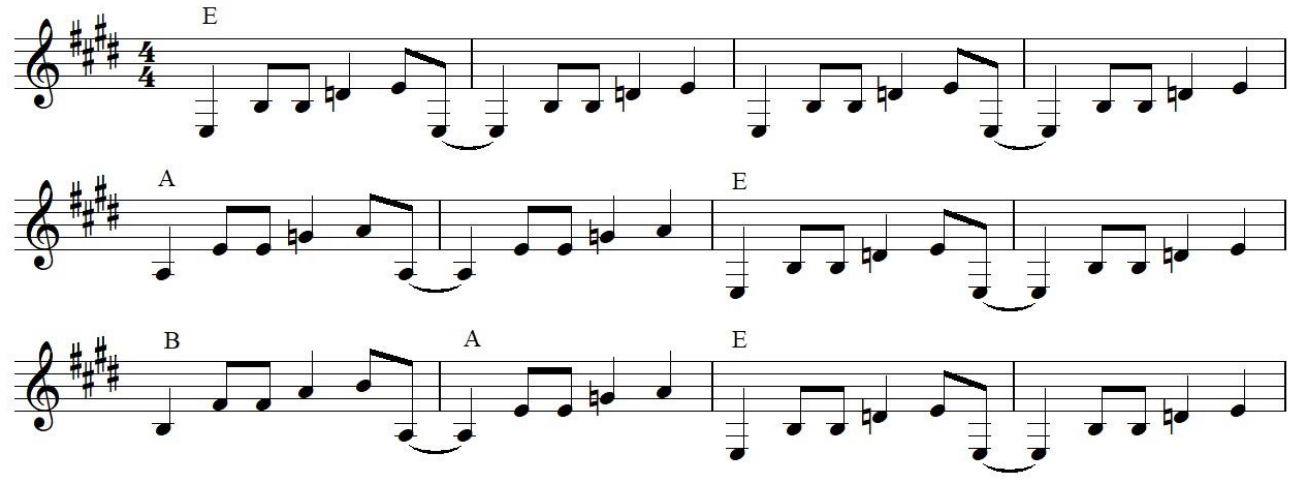

Figure 2 'What'd I Say' (Charles, 1959, transcribed by Author)

Using Fisher's justification of tunes in place of exercises it is argued that 'What'd I Say' has the same pedagogical function as the exercise, however, presents it in a more aesthetically pleasing manner for the student and is therefore of more pedagogical value. This process was utilised to examine the content of the highest ranking twenty tunes from each data source. Other publications used for cross referencing purposes include Complete Method for Modern Guitar (Bay, 1948), Be Dangerous on Rock Guitar (Daniels, 1986), Hal Leonard Guitar Method (Schmidt, 1977), A Modern Method for Guitar (Leavitt, 1966), Complete Course in Jazz Guitar (Baker, 1955) and Progressive Rhythm Guitar (Turner \& White, 1979b). These publications were chosen due to their status within the Australian guitar community and their historical significance with the wider global guitar community. Another consideration in the determination of each song's pedagogical value was skills transferability. Tunes which contained content that was relevant for a high 
number of other compositions were also considered of high pedagogical value and therefore greater status for the canon being derived in this study. For example, the Bob Dylan composition 'All Along the Watchtower' was found to contain a harmonic progression that was very common and with the addition of another chord produced another progression that was also extremely common. This presents a high level of skills transferability and opportunities for a tutor to present further skills development in a scaffolded progressive fashion. Figure 3 shows the chord progressions found in Dylan's 'All Along the Watchtower' and the Percy Mayfield composition 'Hit the Road Jack' presented in the key of C minor for comparison.

All Along the Watchtower

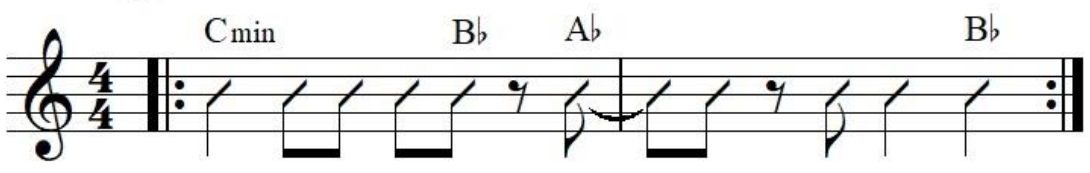

Hit the Road Jack

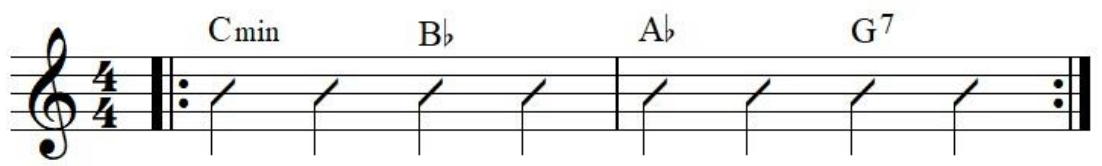

Figure 3 'All Long the Watchtower' (Dylan, 1968) and 'Hit the Road Jack'(Mayfield, 1960) (Transcribed by author).

It is argued that the skills introduced by learning 'All along the Watchtower' can be further developed to learn 'Hit the Road Jack' and many other compositions with similar chord progressions. Therefore, as 'All along the Watchtower' presents the skill set in its simplest form it has foundational pedagogical value as seen from the perspective of the development of the canon in this study.

This musical content analytical stage of the study was followed by the development of an instrumental tutor's personal curriculum for a global perspective guitar tutorial program, designed around the use of a ten-song canon. Qualitative data analysis was conducted into each song to also verify its historical significance, and cultural status in the global guitar community.

\section{Findings}

From the data collected by the methods listed above and the subsequent analysis via the mixed methodology approach utilised, a canon for electric guitar was derived comprising ten songs. Limiting the canon to ten songs was chosen to manage the 
scope of the study and also to fit with industry standards where 'Top Ten' is a common theme. Table 3 presents the canon and includes cultural and historical data.

Table 3

Electric Guitar Canon, Cultural and Historical Details

\begin{tabular}{|l|l|l|l|}
\hline Song title & Composer(s) & $\begin{array}{l}\text { Country } \\
\text { of origin }\end{array}$ & $\begin{array}{l}\text { Date of } \\
\text { release }\end{array}$ \\
\hline Do Re Mi & $\begin{array}{l}\text { Richard Rogers and Oscar } \\
\text { Hammerstein }\end{array}$ & USA & 1959 \\
\hline $\begin{array}{l}\text { Sweet Home } \\
\text { Alabama }\end{array}$ & $\begin{array}{l}\text { Ed King, Gary Rossington and Ronnie } \\
\text { Van Zant }\end{array}$ & USA & 1974 \\
\hline What'd I Say & Ray Charles & USA & 1959 \\
\hline $\begin{array}{l}\text { All Along the } \\
\text { Watchtower }\end{array}$ & Bob Dylan & USA & 1968 \\
\hline Boom Boom & John Lee Hooker & USA & 1962 \\
\hline $\begin{array}{l}\text { Sunshine of Your } \\
\text { Love }\end{array}$ & $\begin{array}{l}\text { Pete Brown, Jack Bruce and Eric } \\
\text { Clapton }\end{array}$ & UK & 1968 \\
\hline Layla & Eric Clapton \& Jim Gordon & UK & 1972 \\
\hline Johnny B Goode & Chuck Berry & USA & 1958 \\
\hline $\begin{array}{l}\text { Sweet Child O' } \\
\text { Mine }\end{array}$ & $\begin{array}{l}\text { William Rose, Saul Hudson and } \\
\text { Jeffrey Isbell }\end{array}$ & USA & 1988 \\
\hline $\begin{array}{l}\text { Stairway to } \\
\text { Heaven }\end{array}$ & James Page and Robert Plant & UK & 1971 \\
\hline
\end{tabular}

Three of the songs within the canon were released in the 1950's, three in the 1960 's, three in the 1970's and one in the 1980's. This represents a broad spread across the history of the electric guitar and gives a sense of the period of time required for a song to reach canonical status. A broad spread of popular music genres is represented with blues, country rock and heavy rock all being represented in conjunction with mainstream rock and roll. 'Do Re Mi' is the only song composed for use in a musical. All of the songs have been featured in movies and also appear frequently throughout popular culture. 'Do Re Mi' did not appear on the top twenty lists of the three data sets. However, it can be considered a prime exemplar for teaching the Major scale, which other tunes in the list also include, and therefore was included in the canon. It could, at the will of an instrumental tutor, be interchanged with other socio-culturally relevant Major scale tunes including "the Flintstones Theme" which can be found in the tutor log data set. 


\section{Discussion}

This paper's main aim is to discuss the cultural significance of the canon developed in the study from the perspective of Australian electric guitar culture. It was observed that within the canon derived in the study there are no songs composed by Australian composers. This may indicate a possible attitude that Australian music is not valued globally within the paradigm of electric guitar culture. It is, however, reflective of the Australian guitar culture in general; 'for the most part Australians followed America and Britain in embracing the guitar' (Johnson \& Gordon, 2011, p. $\mathrm{xx}$ ). This may have led to a potential stifling of a uniquely Australian electric guitar culture via the widespread use of pedagogical methodologies that have simply adopted international content rather than focussed on development of local input. This phenomenon has also been observed to be problematic in other countries including Ghana (Otchere, 2015) where it was found that only a small proportion of music being taught in local universities was of African origin. Otchere argues that teaching music is an effective way of teaching about culture as a whole and it is the role of the education system to both maintain and further develop local cultures. Other studies in Thailand (Putipumnak, 2018) and Malaysia (Shah \& Saidon, 2017) support the role of music education in helping shape cultural identities and the development of local curricula. Musaeva, Chan and Augustine (2017) highlight the pertinence of addressing this phenomenon due to the twenty-first century technological developments in communication and the easy access to non-local cultural influences.

Within the quantitative data, the top-ranking songs composed by Australian artists were by $\mathrm{AC} / \mathrm{DC}$, one of Australia's most successful music industry exports. However, the research found that their compositions offered no unique pedagogical qualities for a global electric guitar canon that were not found in compositions by American guitarists. The song 'Back in Black' ranked highly in the data, however, when examined for guitar pedagogical content, it was found to be a re-working of the blues artists' products from the previous generation. This fits with AC/DC guitarist, Angus Young's (b1955) own perspective of the birth of rock and roll; 'Rock music has been around since the days when Chuck Berry put it all together. He combined the blues, country and rockabilly and put his own poetry on top and that became rock and roll' (Young, 2015, p. 1). Congruent with the results of the qualitative research, this also fits well with Young's early learning styles. He was self-taught resourcing himself with blues records and lessons in magazines:

Because we grew up in Australia, to find information about a lot of blues guys I used to go to the library and find the jazz magazines. They didn't even sell them at the time in newsagents and stuff. So I'd go into the library and read all about what these people were playing, like Muddy Waters and Elmore James. (Young, 2001 para. 10)

This presents an image of a person who was serious about his own music education, however, the system of guitar education in Australia at the time was not 
meeting his personal needs. Young understood the content and direction his learning needed to take and became self reliant on resources out of necessity. However, this was at the expense of learning from and also investing in local culture. Young's guitar riff in the AC/DC song 'Thunderstruck' resembles a technical exercise similar to many found in the American method books. Figures 4 and 5 show a comparison of the riff in 'Thunderstruck' and an etude from Mel Bay's 1948 Modern Method for Guitar.

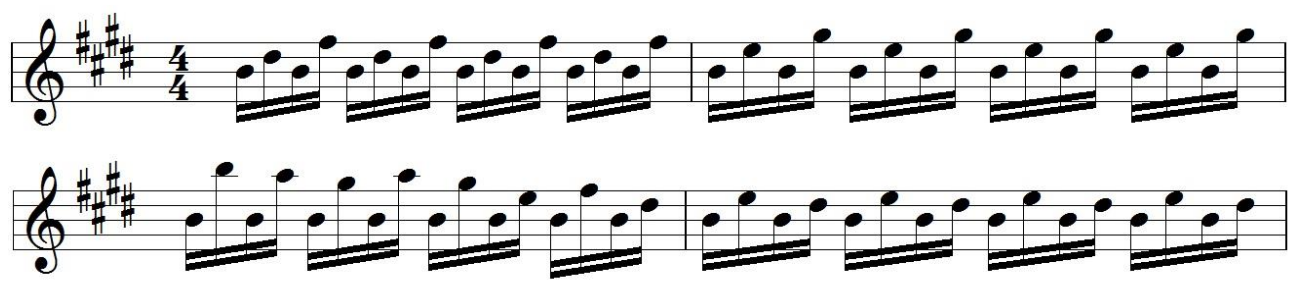

Figure 4. 'Thunderstruck', main riff (Young \& Young, 1990, transcribed by author)

\section{Etude}
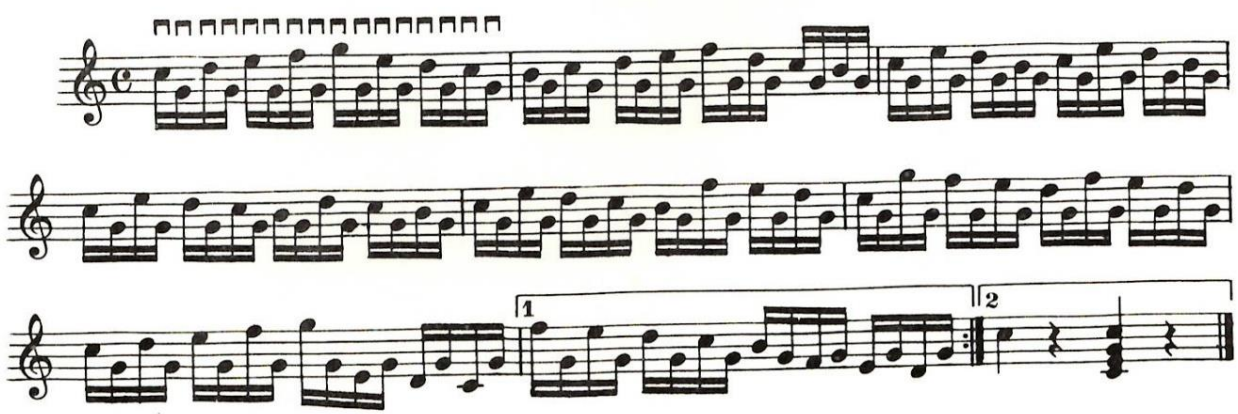

Figure 5. 'Etude' - Mel Bay (Bay, 1948, p. 39)

These two examples, together with examinations of earlier blues compositions, including John Lee Hooker's 'Boom Boom' in back to back comparison with 'Back in Black', do not show any musically annotatable content of distinct Australian cultural origin being added to the global guitar pedagogy by AC/DC. This may suggest that at the time, there was nothing unique, from an international perspective, within the Australian electric guitar culture. The study found that Australian rock and roll guitar culture is a hybrid of the corresponding American and British cultures. There were some unique Australian inventions found within the paradigm of this study, but none were significant enough to manifest in the canon using the methodology chosen.

One aspect of Australian music culture that does stand out is the pub-rock flavour of Australian music. This can be found in the music of Australia's biggest 
rock exports AC/DC, INXS, Men at Work and Silverchair, as well as more recent bands including Jet and Wolfmother. Figure 6 shows an excerpt from Wolfmother's song 'Joker and the Thief'. Here we see another similarity with Mel Bay's Etude in figure 2 and AC/DC's 'Thunderstruck', suggesting a long- lasting influence of AC/DC.

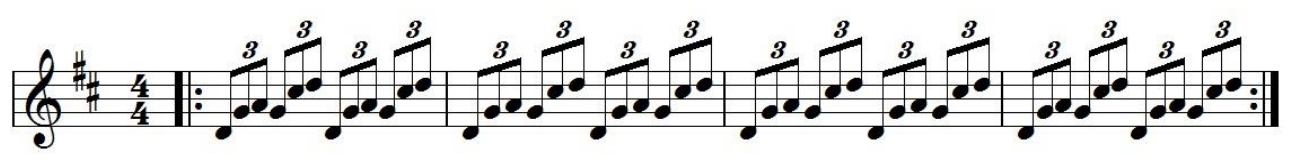

Figure 6. 'Joker and the Thief', opening riff (Stockdale, Ross \& Heskett, 2005, transcribed by author)

A 2014 market report showed electric guitars were the best selling musical instruments in Australia and their growing market share is reinforcing 'the guitar's continued standing as the preeminent instrument in popular music' (AMA, 2015). Historically, guitars have been part of Australian culture since white settlement: "... it can safely be assumed that the earliest arrivals to Australia brought a good many [guitars] with them" (Johnson, 2011, p. 16). The popularity of the guitar within Australia rapidly rose after World War Two:

Yet while rock and roll may have catapulted sales, guitars have always been popular. It is true in Australia as much as anywhere else in the world. The early folk music surges of the forties ... played their part in keeping the instrument a common sight on Australian verandahs ... as well as concert venues and dance halls. (Johnson, 2011, p. 3)

The electric guitar's popularity first boomed after the birth of rock and roll: "This country followed America in the fifties with a rush on guitar sales at the birth of rock and roll"' (Johnson, 2011, p. 3).

\section{The Electric Guitar in Australia - History and Education}

It has been established that the electric guitar is popular in Australia and consequently has a strong position in local culture. This raises a question regarding why we have not created a globally recognised guitar style. Is it not reasonable to have expected by 2015, we would find a uniquely local electric guitar culture? Discussing the late nineteenth century and early twentieth century situation in Australia, Johnson (2011) states; "Classical guitar playing was itself very much based on the European study and, despite some classical compositions showing small signs of folk influence, the European tradition reigned until well into the twentieth century" (p. 17). This attitude may have set the foundations for what was to follow with the electric guitar. Free instrumental music tuition in Australian 
government schools commenced in 1962, providing private, one on one, tuition (Lierse, 2005, p. 277). The formal training of instrumental music tutors in the early sixties is assumed to have been in the European Classical genre. These tutor's own traditional styles and methodologies may not have been relevant to the students wishing to learn blues based American music which had evolved through an aural tradition. The formalised method books offered technical exercises, however, these books also offered little relevance. As a result, electric guitar students often learnt by aurally copying American and British music. We have seen the attitude of Young in being self-reliant on resources. His only lessons were "... in the form of watching his brother play" and "listening mainly to old rock and roll records a la Chuck Berry" (Rosen, 2011 para 11).

Another example of this paradigm is Ian Moss (b1955), lead guitarist from Australian rock band Cold Chisel. He grew up in Alice Springs, in Central Australia, first learning to play the guitar there. However, Moss was also self-taught by transcribing from records, which due to his remote locale needed an extra level of perseverance; "If you heard a song on the radio it took an eternity for your local store to get that single" (Moss, 2015). We see here another guitarist who was serious about his musical education and used the most relevant, available resources to achieve his goals.

Cold Chisel songs are generally recognised for their deep lyrical content which fit the bush ballad style of story telling narratives. The cultural value of this has not gone unrecognised as "Chisel songs [are] forever immortalised in Australia's music canon" (Delaney, 2015 para 17) and more than one of their songs, 'Khe Sahn', 'Bow River' and 'Flame Trees', have each, in turn, been glorified as Australia's unofficial national Anthem (Delany, 2015). However this study is about the electric guitar's position in Australian culture rather than lyricists. Moss is now recognised as one of the greatest guitarists in Australia, typically topping polls of local musicians, listeners and music journalists. He offers something distinctive to the Australian guitar culture because "... he has used his influences to mould a unique musical voice, rather than a transparent template of what has come before him" (Laska, 2015 para 19). However, Cold Chisel's commercial success overseas has been limited. Due to this, Moss's unique guitar playing has not made significant inroads into the international electric guitar culture. Therefore, due to the methodology chosen for this study, his influence was not evidenced in this study.

Tommy Emmanuel's story also shares the common thread of self-resourced education. Growing up in Muswellbrook, a small country town in New South Wales, his mother showed him the basics so he could accompany her while she played the lapsteel. From then he has been entirely self-taught, transcribing by ear: "I learnt everything by ear. I have never read a piece of music in my life ... I can do it quicker by ear. I tried to learn to read music when I was about eighteen years old and I was just no good at it" (Emmanuel, n.d. para. 13). The common thread we see among significant figures in the Australian guitar culture is a desire and passion for up to date music that outpaced the educational resources of the time.

The Easybeats were the first Australian rock and roll group to have an international hit. The formation of the band has been regarded, by a panel of experts, 
as the greatest moment in Australian rock music history (Kerin, 2007). Their hit single 'Friday on my Mind' from 1966 reached number six on the UK charts and number 16 in the United States of America. The guitar part to 'Friday on my Mind' is also similar to the picking etudes found in the method books. All five members of the original line-up were from families that migrated from the United Kingdom and Europe to Australia after World War Two. The musical flavor of the Easybeats was similar to the British invasion bands of the same period. Their name suggests homage to the Beatles. Similarly, all but one of the members of AC/DC were born in Scotland and migrated to Australia in their childhood prior to 1960. When their lead singer Bon Scott died in 1980, he was replaced with Scottish born Brian Johnson. A common thread of migration families can be found within the stories of other early Australian music icons. How much this had an effect on their music is not clear. However, it cannot go unnoticed in an analysis of the place of Australian musicians within the global electric guitar culture paradigm.

An examination of the Australian published method books also reveals the impact of the United Kingdom and United States of America's cultural influence on local music. The first two books in the Koala Publications' Progressive series published in 1979 (Turner \& White) feature little Australian content. With the exception of the exercises composed by the authors all the musical examples are from the UK or USA. Their Guitar Method Book 2 from 1996 begins with the C Major Scale then follows with the traditional Irish song 'Londonderry Air', 'Country Gardens' from the United Kingdom, then after some chord exercises 'Banks of the Ohio'. Throughout the book there are songs from other cultures as diverse as Spanish, Russian, Caribbean and German. There are no songs featured by Australian composers. The Progressive series Guitar Method Book 1 does, however, contain 'Waltzing Matilda'. It was found that this lack of local content in Australian published method books extends back to the earliest examples. Don Andrews' Plectrum Method Book 1, from 1971, also contains no Australian composed content other than the author's own etudes and exercises, but instead draws upon the repertoire from other Western cultures.

\section{The Electric Guitar in Australian Indigenous Music}

One area that Australian musicians have had an opportunity to express a unique voice and potentially influence global music culture is within the paradigm of Indigenous Australian music. Within this sub-genre, the musicians using electric guitars typically utilise Western techniques and musical concepts with the superimposition of Indigenous instruments and lyrical content. It was observed by the researcher that the contemporary indigenous music had a strong reggae influence and it could be suggested that this is due to links to shared themes of cultural oppression. As such, no uniquely Australian new musical or pedagogical content can be found within the indigenous peoples' popular music from the perspective of electric guitar education and for the purposes of a pedagogical guitar canon. 


\section{Global Electric Guitar Culture}

If one teaches music from another culture in place of local content, there is a risk of students not learning their own cultural heritage. This could potentially lead to a global mono-culture and a loss of localised cultural identities. However, with careful attention to musical cultures, the electric guitar could be used as a starting point for studying other cultures. Carfoot explains the guitar has "traversed so many $20^{\text {th }}$ century musical cultures' that it becomes a useful way to study socio-cultural ideologies" (Carfoot, 2006, p. 36).

Virag opened his presentation at the 2013 Vancouver TED conference with the following statement: "In recent years technology has completely transformed the way that we listen to music, we share music, access it, create it and perform it" (Virag, 2013). The hyper-connectivity of today's world is making unique musical cultures more difficult to sustain. The position of the electric guitar within Australian culture is already heavily influenced by cultures from the United Kingdom and the United States of America. The future possibilities of Australian guitar culture developing a unique identity within the international perspective may be now greatly reduced by the presence of the internet. In the twenty-first century, students of the guitar are exposed to influence by artists from international cultures as much as they are from their own.

The canon developed in the study is evidence of ongoing international influence within the Australian electric guitar culture. However, it was found that internationalism is not unique to Australia within the paradigm of electric guitar culture. Japanese youth have adopted western rock and roll and its sub-genres and fully immersed themselves into the culture surrounding the music. This is evidenced by audience members during American guitarist Brian Setzer's (b1959) 2001 Japanese tour who showed their commitment to the American culture by sporting rockabilly inspired apparel and hairdos and driving American hot rods. Globalisation and the Internet have influenced the spread of rock and roll culture across Asia. Changes have escalated since the inception of the internet in the early 1990s:

In the late 1990s, the Okinawan popular music scene changed dramatically. A younger generation seems to have appeared, independent from other popular music since postwar Okinawa. Hardcore, punk and hip-hop have won large audiences in Okinawa and some musicians collaborate with musicians abroad in the so-called alternative rock scene. (Ogura, 2003, p. 469)

In 2007, Japan was the second biggest market for electric guitars manufactured in China and the third biggest market for electric guitars manufactured in America (Music Trades, 2011). This global spread of popular music culture also now reaching Africa:

The process of globalisation has been of a tremendous impact on African societies while the status-quo of expressive cultures have obviously not remained the same due to this factor with popular music gradually becoming homogenized to fit into 
the western stereotypes. The Nigerian popular music has been greatly influenced by the dictates and progression in the international scene due to global communication and cultural flows. (Adedeji, 2014, p. 467)

The current status of the various international electric guitar cultures is pointing towards a possible future homogenous musical style. Further research into the influence of globalisation and the potential development of a global monoculture, particularly within the framework of electric guitar cultures, may be needed to assess the situation completely.

\section{Guitars in Australian Popular Music Culture}

According to the Australian Recording Industry Association (ARIA), the biggest selling single in Australia by an Australian artist is 'Somebody that I used to know' by Melbourne artist Gotye (Aria.com.au, 2015). The guitar plays a fundamental role in the accompaniment of this song and there are both acoustic and electric guitars on the recording. The harmonic structure of this song is identical to American composer Bob Dylan's 'All Along the Watchtower', in the key of D Minor. The second best selling single in Australia by an Australian artist is 'Battle Scars' by Adelaide born Guy Sebastian (Aria.com.au, 2015). This song uses the almost ubiquitous harmonic structure demonstrated in the 'Four Chord Song' by Axis of Awesome, typically expressed in Roman Numerals as: I V VIm IV. Third on the list is 'Boom Boom' by Sydney based dance-pop group Justice Crew. (This song bears no similarity to John Lee Hooker's tune of the same name that features in the canon.) Justice Crew's 'Boom Boom' features no harmonic motion at all in the verses or chorus sections. Instead these sections utilise a repeating Minor scale riff. In its bridge section the harmonic structure is again based on that of 'All Along the Watchtower' with some rhythmic displacement. A common thread emerges as one continues down the list. It seems, from this study that, an Australian guitar student could learn the necessary skills to perform Australian popular music using pedagogical methodologies employing repertoire by composers from the United States of America and the United Kingdom. Alternatively it is therefore equally viable that an Australian guitar student could also learn the skills necessary to perform international popular music by studying repertoire by Australian composers.

\section{Instrumental Electric Guitar Music}

There are no instrumental compositions, songs without lyrics, in the electric guitar canon developed in the study. However, instrumental compositions were present in the data researched. The theme from Spiderman and Tommy Emmanuel's 'Stevie's Blues' ranked well in the data. Another instrumental recording within electric guitar 
culture, 'Jessica' appear multiple times in the data. Released in 1973 by The Allman Brothers it has received renewed interest since being adopted, in 2002, by BBC television program Top Gear as their theme and also its inclusion in the 2006 video game Guitar Hero II. 'Miserlou' is a traditional, Middle-Eastern, anonymously composed instrumental tune made popular within the electric guitar culture by Dick Dale's 1962 version. 'Miserlou' has also received renewed interest since being featured on Guitar Hero II and was found in the primary source data. 'Wipeout', an instrumental twelve-bar-blues riff based composition, was also present in the data.

Instrumental music was once common in the popular music sales charts. However, in recent decades this trend has become increasingly rare. In January 2000, Kenny G's instrumental version of 'Auld Lang Syne' reached number seven on the Billboard charts and the only other instrumental to reach the top 40 since is Martin Garrix's 'Animals'. In Europe there is a slightly different picture. In 2006, French electric guitarist Jean-Pierre Danal's instrumental album Guitar Connection reached number one on the French charts. The website Tunecaster.com lists the top 100 instrumental singles since the 1960's. Table 4, formulated from this data, shows the decline in popularity of instrumental music within popular culture over the past five decades:

Table 4

Top 100 Instrumental Songs Since 1960

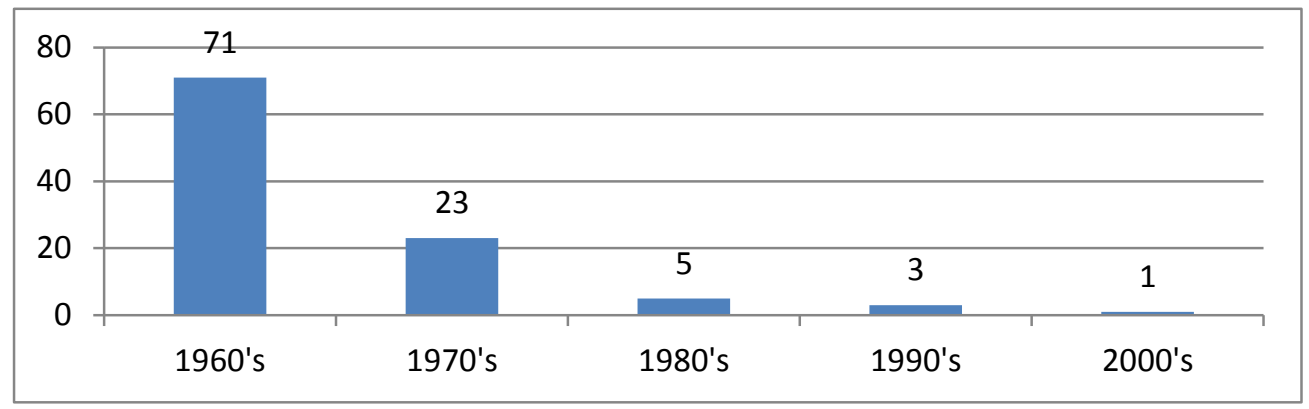

This data is from the United States of America. There is no comparative data readily available for Australian instrumental music sales. However, it is anticipated this trend would be similar in Australia. Instrumental compositions for electric guitar were found to be present only within esoteric guitar culture discourse and there were very few within the data pool. 


\section{Conclusion}

The study investigated the current status of songs within the global electric guitar culture in order to develop a canon derived of culturally and historically significant songs with pedagogical value. By a process of data collection and reduction, followed by triangulation and analysis, the research developed a canon that is grounded in curriculum for electric guitar pedagogy. It was found that no songs in the canon for electric guitar developed in the study were of Australian origin and Australian electric guitar culture is primarily a hybrid of the styles developed in the United Kingdom and the United States of America. Further research might be necessary to investigate the question of the cultural role of curriculum. Should a pedagogical canon, such as the one derived in this study, be formulated with the deliberate intent of enculturation, cultural preservation or, conversely, cultural diversification via music education? If so, how would this best be approached? Are there adequate compositions in the Australian repertoire of guitar based contemporary popular music to address the pedagogical content found in the canon derived in this study? These questions are worthy of further investigation. It is proposed that this topic is relevant in every nation and of growing pertinence since the development of the internet and the rapid cultural exchange it permits.

It is suggested that Australian popular music culture has long had a fascination with American music and this has influenced the pedagogical resources found in this country. Evidence for this can be found in Australian guitar print material since the earliest days of the electric guitar and modern popular music. For example, Australian guitarist Don Andrews' book Jazz Guitar Solos (Andrews, 1961) published in 1961 contains arrangements of entirely American compositions and an advert on the rear cover by the Australian publisher for one of their other publications states 'At last and up to date American tutor has been written for modern guitar'. How much this attitude has influenced the development of any potential uniquely Australian cultural idioms in the electric guitar culture can only be speculated. Whether this is cause for concern is also worthy of further investigation.

It was found that by generating a canon comprising of ten songs as exemplars, a foundation for a curriculum that contained the pedagogical value found in the studies and etudes within conventional guitar method books and tutorials could be established. Recommendations for supplementary repertoire have been left open for a music educator to shape and personalise the curriculum to the individual needs of their students. Bannister writes, "The canon is not a list, but rather a tool of education and a means of distributing cultural capital" (Bannister, 2006, p. 82). This description fits both the canon derived in this study and the findings of the analysis.

The study found the guitar's role in popular culture to be primarily one of a supporting role for singers. Although there were a few cases of the electric guitar taking the lead role in instrumental music, these were the exception rather than the rule. However, in eight of the ten songs the electric guitar played the lead role for a segment of the recording during solo sections. These were mostly improvised solos or riff based introductions. 
A curriculum based on a repertoire of ten songs should ideally contain material that forms the foundation of pedagogical pathways to further repertoire. The presence of the twelve-bar-blues in any canon for modern popular music is vital as it has been the cornerstone of many sub-genres. An electric guitar canon should also include riff based tunes. Within rock and roll it is often the guitar riff that initially captures the listener; "I never remembered the rest of the song, all I remembered was that riff" (Skolnick, 1996, p. 27). For pedagogical value there must also be present in such a canon songs that present opportunities for technical development as well as understanding of fundamental genre theoretical traits. This explains the presence in the canon of the song 'Do Re Mi', an excellent tool for teaching the $\mathrm{C}$ Major scale. A canon for electric guitar should also contain songs with lead guitar solos. Solos are a large part of electric guitar culture; "solos tend to inspire legions of guitarists to attempt to unlock their technical and tonal mysteries and at the very least they permeate the 6-string community's collective unconscious" (Guitar Player Staff, 2011 para 1). Most of all a canon, derived for pedagogical purposes, for the electric guitar must contain songs that are recognisable globally as part of the established electric guitar culture.

\section{References}

Adedeji, W. (2014). Negotiating globalization through hybridization: Hip Hop, language use and the creation of cross-over culture in Nigerian popular music. Language in India, 14(6), 497-515.

AMA (Producer). (2015). Australian attitudes to music. [online article] Retrieved from http://www.australianmusic.asn.au/australian-attitudes-to-music/

Andrews, D. (1961). Jazz guitar solos. Melbourne: J. Albert \& Son Pty Ltd. Aria.com.au (Producer). (2015). Aria charts - accreditation - 2013. Retrieved from http://www.aria.com.au/pages/httpwww.aria.com.aupagesaria-chartsaccreditations-singles-2013.htm.

Baker, M. (1955). Mickey Baker's complete course in jazz guitar. New York, NY: Lewis Music Publishing Co., Inc.

Bannister, M. (2006). Loaded: Indie guitar rock, canonism, white masculinities. Popular music, 25, 77-95. doi:10.1017/S026114300500070X.

Bay, M. (1948). Mel Bay's complete method for modern guitar. Pacific, MO: Mel Bay Publications.

Carfoot, G. (2006). Acoustic, electric and virtual noise: The cultural identity of the guitar. Leonardo Music Journal, 16, 35-39.

Charles, R. (1959). What'd I say. Washington, DC, NY: Atlantic Records.

Daniels, R. (1986). Be dangerous on rock guitar: Port Chester, N.Y: Cherry Lane Music Company.

Delaney, B. (2015, October 16). Cold chisel: Writing Australia's unofficial national anthems since 1973. The Guardian. Retrieved from http://www.theguardian.com/music/2015/oct/06/cold-chisel-writingaustralias-unofficial-national-anthems-since-1973. 
Denzin, N. K., \& Lincoln, Y. S. (2011). The Sage handbook of qualitative research: Thousand Oaks, CA: Sage Publications.

Dylan, B. (1968). All along the watchtower. New York, NY: Columbia Records. Emmanuel, T. (n.d.). MA-001 Tommy Emmanuel. Justin Guitar.com. Retreived from https://www.justinguitar.com/guitar-lessons/tommy-emmanuelinterview-text-ma-001.

Fisher, J. (2005). Teaching guitar. Van Nuys, CA: Alfred publishing.

Johnson, C. N., \& Gordon, C. G. (2011). Guitar: The Australian journey. West Geelong: Barrallier Books.

Kerin, L. (Producer). (June 15, 2007). Easybeats to Oz rock history list. Retrieved from http://www.abc.net.au/news/2007-06-13/easybeats-top-oz-rockhistory-list/68364.

Laska, A. (2015) Who is Australia's best guitarist? News Corp poll reveals top ten players/Interviewer: $K$. McCabe. News.com.au. Retreived from https://www.news.com.au/entertainment/music/who-is-australias-bestguitarist-news-corp-poll-reveals-top-ten-guitar-players/newsstory/793af6493d8e41cca699543dc7daacd2.

Leavitt, W. (1966). A modern method for guitar. Boston, MA: Berklee Press.

Lierse, S. (2005). The development of instrumental music programs in Victorian government schools 1965-2000 (PhD), RMIT. Retrieved from http://researchbank.rmit.edu.au/eserv/rmit:161170/Lierse.pdf (161170).

Mayfield, P. (1960). Hit the road Jack. New York, NY: ABC-Paramount.

Moss, I. (2015). Ian Moss exclusive interview. Do the Yarra Valley, [online article]. Retreived from https://www.dotheyarravalley.com.au/ian-moss-exclusiveinterview/.

Musaeva, M., Chan, C. C. S., \& Augustine, C. (2017). Application of Ivan Galamian principles for Violin learning thwough Malaysian folk tunes. International Journal of Academic Research in Business and Social Sciences, 7(11), 522-536.

Music Trades. (2011). The massive ultimate-guitar online community. Music Trades, February 2011, 182-186.

Ogura, T. (2003). Military base culture and Okinawa Rock ' n' Roll. Inter-Asia Cultural Studies, 4(3), 466-470. doi:10.1080/1464937032000143823.

Otchere, E. (2015). Music teaching and the process of enculturation: A cultural dilemma. British journal of Music Education, 32(3), 291-297. doi:10.1017/S0265051715000352.

Pratchett, T. (2014). A slip of the keyboard: Collected non-fiction: London, UK: Doubleday.

Putipumnak, K. (2018). Paradigm for the development of a Lanna music curriculum in higher education in Northern Thailand Malaysian Journal of Music, 7, 38-57.

Rosen, S. (2011). Angus Young of AC/DC opens up in his first guitar world interview from 1984. Guitar World, August 23, 2015.

Sarantakos, S. (2013). Social research, 4th ed. Basingstoke: Palgrave Macmillan. Schmidt, W. (1977). Hal Leonard guitar method. Winona, MN: Hal Leonard. 
Shahanum Mohd Shah \& Zaharul Lailiddin Saidon (2017). Developing a graded examination for the Malay Gamelan. Malaysian Music Journal, 6(1), 14-29.

Skolnick, A. (1996). In J. A. Stix, Y. (Ed.), Rock riffs for guitar. Milwaukee, WI: Hal Leonard.

Staff, G. P. (2011). The 40 most influential rock guitar solos. Guitar Player, June 15.

Stockdale, A., Ross, C., \& Heskett, M. (2005) Joker and the thief. Sydney: Modular Recordings.

Turner, G., \& White, B. (1979a). Progressive lead guitar. Hindmarsh, South Australia: Koala Publications.

Turner, G., \& White, B. (1979b). Progressive rhythm guitar. Burnside, South Australia: Koala Publications.

Virag, Z. (Producer). (2013). Music education: Collaborative student driven learning. [Video File] Retrieved from https://www.youtube.com/watch?v=CFFrT8xqwwk.

Wise, S. (2014). Mixed methods: The third research community. In K. A. Hartwig (Ed.), Research methodologies in music education (pp. 183-198).

Newcastle, U.K. : Cambridge Scholars Publishing.

Young, A. (May 24 2001) AC/DC's Angus Young: The rock and roll Peter Pan/Interviewer: J. Eluscu. Rolling Stone.

Young, A. (2015) Thirty great guitarists - Including Steve Vai, David Gilmour, and Eddie Van Halen - Pick the greatest guitarists of all time/Interviewer: $G$. W. Staff. [online article]. Retreived from https://www.guitarworld.com/magazine/30-30-greatest-guitarists-pickedgreatest-guitarists.

Young, A. \& Young, M. (1990). Thunderstruck. New York, NY: ATCO Records

\section{Biography}

Daniel Lee is an Australian musician and educator with over 20 years experience in primary, secondary and tertiary institutions. After graduating from Elder Conservatorium with a degree in jazz guitar performance he has pursued a career balancing performing and educating. From directing jazz orchestras to performing solo gigs and everything in between, he brings his experience as a performer to his education, aiming to maintain industry relevance at all times. Following his undergraduate studies and modelling his passion for life-long learning he has completed a post-graduate diploma in education and a Masters degree in international education. He is currently enrolled in a $\mathrm{PhD}$ in music education. 